\title{
Bank Failure Prediction Model for Zimbabwe
}

\author{
Victor Gumbo (PhD, CBiiPro) ${ }^{1}$, Simba Zoromedza (MSc) ${ }^{2}$ \\ ${ }^{1}$ Department of Finance, National University of Science and Technology, Bulawayo, Zimbabwe. \\ ${ }^{2}$ Department of Finance, National University of Science and Technology, Bulawayo, Zimbabwe. \\ Correspondence: Victor Gumbo, Department of Finance, National University of Science and Technology, Bulawayo, \\ Zimbabwe.
}

Received: April 28, 2016

Accepted: May 12, 2016

Available online: May 27, 2016

doi:10.11114/aef.v3i3.1639

URL: http://dx.doi.org/10.11114/aef.v3i3.1639

\begin{abstract}
Probability of Default (PD) is a financial term describing the likelihood of default over a particular time horizon. This concept has attracted a lot of interest ever since the late 1960's and has been extended to the banking sector to predict probability of failure as well as bank performance ratings. We derive the probability of bankruptcy and bank ratings in a Zimbabwean context based on data between 2009 and 2013, inclusive.

We build a model to predict the probability of bank failure twelve months in advance for Zimbabwean banks based on twelve micro factors. Further, we build the corresponding rating model. The empirical analysis revealed that the warning signal so developed produced a robust result with a high prediction accuracy of $92.31 \%$ compared to $60 \%$ of the Altman's Z Score model.
\end{abstract}

Keywords: Bankruptcy, early warning systems, bank failure.

JEL Classifications: C19, C22, C32, E43, E44, G10, F59

\section{Introduction}

Zimbabwe has experienced a significant number of bank failures in recent years, some of which could have been avoided. Early detection of bank failure is a matter of concern to bank regulators worldwide as it is probably the best way to minimise and avoid systemic risk by taking prompt corrective action before the propagation of the problem. Given the recent episodes of banking crises, bank failure prediction has rekindled the interest in the adoption of suitable early warning systems in bank supervision and regulation. Bank failures continue to occur despite tightening regulations imposed by regulators worldwide. This study sought to explore the development and adoption of an early warning system which can estimate bank rating and probability of failure twelve months in advance for Zimbabwean banks.

As at end of 2013, the Zimbabwean banking sector comprised of twenty one banking institutions, one savings bank and four building societies. The table below shows the negative growth trends of total banking institutions in the country which declined by $38.10 \%$ over the ten year period.

Table 1.1 Architecture of Zimbabwean Banking Sector 2004 - 2013

\begin{tabular}{lccccccc}
\hline & Dec-04 & Dec-08 & Dec-09 & Dec-10 & Dec-11 & Dec-12 & Dec-13 \\
\hline Banking Institutions & 23 & 21 & 21 & 20 & 23 & 22 & 21 \\
Finance House & 6 & 0 & 0 & 0 & 0 & 0 & 0 \\
Discount House & 6 & 3 & 1 & 0 & 0 & 0 & 0 \\
Building Society & 6 & 4 & 4 & 4 & 4 & 4 & 4 \\
Savings & 1 & 1 & 1 & 1 & 1 & 1 & 1 \\
Total & 42 & 29 & 27 & 25 & 28 & 27 & 26 \\
\hline
\end{tabular}

Source: Compilation from Monetary Policy Statements, 2004 - 2013

The negative trend has remained an issue to the Monetary Authorities and the government at large as the sector continues to be dogged by a number of weak banks, with high credit risks, deteriorating asset quality and high non-performing loans (Monetary Policy June 2013). The vulnerabilities in the sector have eroded customer confidence, particularly in smaller banks, resulting in a flow of deposits to bigger banks, which are perceived to be stable resulting in the top five banks controlling a combined 65\% market share of market deposits (Monetary Policy January 2014). The Monetary Authorities have responded to the bank failures by calling for the consolidation of the banking sector and the 
strengthening of governance in the sector as some of the solutions.

The IMF Article IV Consultation Report released in June 2014 also highlighted that the financial sector vulnerabilities continue to persist, stemming from the high levels of non-performing loans (16.6\% on average for banks in March 2014), low capitalization and low liquidity with wide differentiation across banks. To enhance stability, it was noted that the Reserve Bank of Zimbabwe (RBZ) had taken steps to enhance the legal and regulatory framework. In January 2014, banks were instructed to immediately end new insider lending and their Boards are now required to ensure adequate provisioning and submit regular reports. In addition, the deadline for meeting the minimum capital requirement of US $\$ 100$ million was extended to December 2020 though recapitalization plans which were due by end of June 2014, with interim milestones to ensure compliance.

Though the regulator is putting in measures to stabilise the banking sector, this is a reactionary strategy. Hence, against this background, there is need for the Central Bank to adopt new strategies on the regulation and supervision of banks given the highly fragile operating environment.

\section{Impact Of Bank Failures}

Empirical evidence shows that bank failures are usually a cost burden to the economy as noted in an International Monetary Fund (IMF) study that found that fiscal costs associated with bank failures can range from 3 percent of GDP as experienced in the United States to as high as 50 percent of GDP as experienced in Chile and Indonesia (IMF, 2003). After the financial regulation in 2000, Kenya suffered thirty nine bank failures which cost $10 \%$ of its GDP in terms of loans and grants for restructuring, compensating depositors and outright losses due to depositor funds not covered by the Deposit Protection Fund compensation scheme (Mamo 2011). In July 2014, the South African Reserve Bank had to save the collapsed African Bank (ABIL) by placing it under curatorship and injecting USD 1 billion.

Elegbe (2013) examined the effect of bank failure on Nigerian economic development using data from 2001 to 2010 and found that a percentage increase in non-performing loans hampered GDP by $1.57 \%$ while an increase in interest rate reduced the economy by $8.48 \%$. Industrial production shrinked by $0.15 \%$ due to a $1 \%$ increase in non-performing loans and bank failures had a contagious effect on industrial output reducing it by $0.29 \%$ invariably undermining consistent economic development.

It therefore becomes imperative for a country's authorities to safeguard the banking system. Accomplishing this goal requires providing banks with a sound macroeconomic environment, supervising and regulating effectively to ensure good corporate governance and prudent risk management (Enoch and Green, 1997).

\subsection{Definition of Bank Failure}

Most of the literature on banking distress defines bank failure when the financial institution either received external support or was directly closed. Gonzalez-Hermosillo (1996) defined a bank failure as when a:

$\checkmark$ Financial institution was recapitalized by either the Central Bank (liquidity injection) or by a strategic investor,

$\checkmark$ Financial institution was acquired by another financial institution,

$\checkmark$ Financial institution surrendered its banking license,

$\checkmark$ Financial institution's operations or license was temporarily suspended by the regulatory authority or

$\checkmark$ Regulatory authority closed the financial institution.

This categorization is intended as a broader concept of bank fragility rather than the more restrictive de jure failure (i.e. shut down). For the purposes of this research, bank failure encompasses any of the above mentioned conditions.

\subsection{Data Sources and Characteristics}

It is clear that if a failure prediction model is eventually to be used in a predictive context, the samples of failing and non-failing firms used for estimation of the model should be representative of the whole population of firms (Ooghe \& Joos, 1995). In order to limit bias of selection and also given the relatively small number of banking institutions and the failed banks in Zimbabwe, we focused on all banks, both failed and non-failed between 2009 and 2013. The data was extracted from the Central Bank database for the period 2009 - 2013. Annual reports were also obtained from respective banks' websites for the period under study and used as secondary data sources. For the failed banks, one-year-prior-to-failure data was extracted except for Genesis Bank where financial data for 2009 could not be obtained.

\section{The Modelling Approach}

Various approaches have been used by researchers for modelling default frequencies which include the Bayesian method, ANN model, probit model and logit model though logistic regression has been used considerably a lot in bank failure prediction. Studies on banking crises/fragility prediction have extensively used the probit/logit framework 
(Demirgüç-Kunt \& Detragiache, 1998; Beck, Demirgüç-Kunt, \& Levine), hence we follow a similar approach. Selection and Justification of Independent Variables

The following table describes the independent variables used in the model, how they are deduced for the purposes of the model as well as the a priori signs.

Table 1.2 Independent Variables Used \& Explanations

\begin{tabular}{|c|c|c|c|}
\hline Variable & Explanation & Calculation & A priori Sign \\
\hline LN_Afr & Log of Shareholders Funds & Shareholder`s Funds On Balance Sheet & - \\
\hline Non_Perf_Loans & Non Performing Loans Ratio & $\begin{array}{l}\text { Total Substandard, Doubtful \& Loss Loans } \\
\text { /Total Exposures }\end{array}$ & + \\
\hline Insider Loans & Insider Loans Ratio & Insider \& Related Exposures/Total Exposures & + \\
\hline Mgt_Av_Exp & $\begin{array}{c}\text { Average Experience of Executive } \\
\text { Directors }\end{array}$ & $\begin{array}{l}\text { Executive Directors Total Banking } \\
\text { Experience/Number of Executive Directors }\end{array}$ & - \\
\hline ROE & Return On Equity & Net Profit After Tax/Shareholder`s Funds & - \\
\hline WACOF & Weighted Average Cost Of Funds & Total Interest Expense/Average Deposit Size & + \\
\hline Prud_Liq_Ratio & Prudential Liquidity Ratio & Liquid Assets/Short Term Liabilities & - \\
\hline Bank_Size & Average Deposit Market Share & Bank Size Of Deposits/Market Deposits & - \\
\hline Larg_Shareholder & Largest Shareholder Shareholding & Largest Shareholding/Total Shares & + \\
\hline Bank_Age & Years Bank in Existence & $\begin{array}{l}\text { Date of Publication less Date the Bank was } \\
\text { incorporated in Zimbabwe }\end{array}$ & - \\
\hline Board_Att & Main Board Meetings Attendance Ratio & $\begin{array}{l}\text { Sum Of Attendance For All Board Members / } \\
\text { Number of Meetings Held In A Year }\end{array}$ & - \\
\hline Founder_Director & $\begin{array}{l}\text { If Founder Is Still Active In The } \\
\text { Management Of The Bank }\end{array}$ & If Founder is active in Bank $=1$ and 0 otherwise & $+/-$ \\
\hline
\end{tabular}

Given the variable explanation above, the logit model then takes the form

$Z=\beta_{0}+\beta_{1} L N_{-} A f r+\beta_{2}$ Non_Perf_Loans $+\beta_{3}$ Insider_Loans $+\beta 4$ Mgt_Av_Exp $+\beta_{5} R O E+\beta_{6}$ WACOF $+\beta_{7}$

Prud_Liq_Ratio $+\beta_{8}$ Bank_Size $+\beta_{9}$ Larg_Shareholder $+\beta_{10}$ Bank_Age $+\beta_{11}$ Board_Att $+\beta_{12}$ Active_Founder

The study was focused on micro bank failure prediction and therefore the model excluded macroeconomic variables because all banks were assumed to face similar conditions and the main idea was to understand the connection between bank stability (or instability) and financial ratios based on the bank balance sheet.

The selection of variables was mainly motivated by several articles which were published in the local media over the past two years as well as the RBZ explanations on the causes of the banking challenges being experienced in the country. In her maiden Monetary Policy Statement (January 2014), Dr Charity Dhliwayo blamed insider lending, non-performing loans, under capitalization as well as poor corporate governance practices as the panacea to the banking challenges. Lance Mambondiani, in an article titled "Is RBZ Doing Enough?" in The Newsday of 02 August 2012 argued that the Central Bank has to achieve equilibrium while focusing on the core of the problem - ownership concentration, connected lending and addressing the problem with non-performing loans. He postulated that the major problem with the Zimbabwean banking crisis has been insider ownership concentration which has resulted in corporate governance weaknesses in private indigenous banks such as insider lending, abuse of depositors' funds and speculative activities.

These postulations motivated the selection of these variables to assess if they do actually impact on bank fragility. We also chose variables which are not commonly used so as to avoid window dressing of financials by some banks to avoid bias. For example, banks such as AfrAsia and Agribank at one time had capital adequacy ratios of $13.4 \%$ and $15.11 \%$ but were inadequately capitalised in terms of regulatory capital at USD8.71 million and USD12.57 million respectively. If the model is built using the traditional capital adequacy ratio, this will result in some bias since banks in Zimbabwe generally do not have models that feed into the proper calculation of risk-weighted assets.

Next we look into the possible influence of each independent variable. 


\subsection{Available Financial Resources (Shareholder`s Funds)}

The capital base of a bank is vital for the protection of its depositors and hence for the maintenance of general confidence in its operations and the under-pinning of its long-term stability and growth. Goodhart et al. (1998) concluded that as a bank's capital decreases, the higher the motivation for actions towards survival. Therefore, the risk of failure rises with the decline of capital. A priori, capitalisation and bank failure are negatively correlated.

\subsubsection{Non-Performing Loans Ratio}

Dermirgue-Kunt (1989), Barr and Siems (1994) found out that asset quality is a statistically significant predictor of insolvency and that failing banking institutions always have high levels of non-performing loans prior to failure. A priori, a positive relationship with probability of failure is expected.

\subsubsection{Insider Loans Ratio}

In her Monetary Policy Statement for January 2014, the then RBZ Acting Governor lamented the impact insider loans had caused on the banks and subsequently banned new disbursements of insider loans as these were blamed to be driving non-performing loans. Insider loans are a result of affiliated parties getting unjustified loans from commercial banks. Insider and related party funding is associated with poor corporate governance structures which result in them being weakly monitored, creating a room for diversion of funds from the intended purpose and weakens the capital position of the bank given that these are deducted from capital. A positive relationship between insider loans and probability of bank failure is anticipated.

\subsubsection{Executive Directors Average Working Experience in Years}

This variable was used as a proxy for management quality which is difficult to measure objectively based on financial statement data. Dziobek and Pazarbasioglu (1997) found that deficient bank management and controls (in conjunction with other factors) is capable of causing bank failures. A related study "An Evaluation of the Factors Contributing to the Failure of National Banks in US - 2011" indicated how important the CEO is by showing that sixty-three percent of the failed banks had CEOs that clearly lacked the capability, experience or integrity necessary to make their banks successful. We used average working experience for the executive directors as a measure of management quality to assess the impact on probability of failure of a bank since bank decision making rests with the Executive Committee (EXCO) comprised of the executive directors. A negative relationship was expected, i.e., as average experience increases, probability of failure reduces.

\subsubsection{Return on Equity (RoE)}

Profits allow companies to implement their investment strategies and grow. Unsurprisingly, past studies have found profitability to be negatively related to the probability of failure (e.g. Wheelock and Wilson, 2000; Lanine and Vander Vennet, 2006). The profitability of the bank should be considered the driving factor for both the liquidity and solidity aspects. In the long run, a bank must generate a sufficient margin on its operations for it to be able to service its debt. Return on equity is a measure of the returns on shareholder funds, hence quantifies a bank's efficiency in generating profits from every unit of shareholder funds. A high ratio implies high profitability and is therefore expected to exhibit a negative relationship with the probability of failure.

\subsubsection{Prudential Liquidity Ratio}

Although most bank failures are caused by insolvency, serious liquidity problems can cause an otherwise solvent bank to fail under certain conditions (Diamond and Dybvig, 1983). In the determination of liquidity risk, it is vital to not only focus on current sources of liquidity and funding needs, but also to focus on future sources of liquidity and future funding needs. Consequently, in order to operate in a sound manner, banks need to maintain a level of liquidity sufficient to meet current as well as future financial obligations. This implies that a bank should be able to manage unanticipated changes in funding sources and to manage unanticipated market conditions that directly affect the liquidity of assets. Hence, liquidity risk is based on current liquidity, future liquidity and the ability to ensure that liquidity can be maintained. Liquidity ratio measures a bank's ability to withstand a possible deposit run-off. It measures what percentage of customer funds and short-term funds could be met if they were withdrawn unexpectedly. The liquidity position of the banking system is very relevant for the study sample given that the market is currently characterized by a high turnover of deposits and limited alternative sources of funding (IMF, 2012b). The higher this ratio is, the higher the liquidity. The relation between this ratio and the probability of failure is expected to be negative.

\subsubsection{Bank Size}

Besides non-accounting and qualitative variables, general characteristics concerning the bank size have proven to be very important variables in failure prediction. On one hand, the literature on the relationship between bank size and stability has found ambiguous results for banks in the U.S (Boyd and Runkle, 1993; Calomiris and Mason, 2000; Chung, 2004; Hughes and Mester, 1998, among others). De Nicolo (2000), on the other hand, found a positive and significant 
relationship between bank size and the probability of failure for banks in the U.S., Japan and several European countries. Apart from the intrinsic relationship between bank size and stability, larger banks might also be less likely to fail as they are considered to be too important to fail (e.g. Mishkin, 1999).

\subsubsection{Shareholder Structure}

One of the several regulatory responses to the financial crisis has been to consider the extent to which bank failure can be explained by flaws in the banks' corporate governance arrangements (Kirkpatrick, 2009). In Zimbabwe, the Banking Act and the proposed amendments to the Act stipulate that neither an individual nor company must hold more than 5\% and $25 \%$ shareholding respectively in order to manage influence of largest and dominant shareholders. Brownbridge (1998) noted that insider lending was the excessive concentration of ownership. He found that in many of the failed banks in Africa, the majority of shares were held by one man or one family, while managers lacked sufficient independence from interference by owners in operational decisions. A more diversified ownership structure and a more independent management are expected to impose greater constraints on insider lending, because at least some of the directors would stand to lose more than they gain from insider lending, while managers would not want to risk their reputations and careers.

\subsubsection{Bank Age}

DeYoung (1999) found that bank age influences the risk of failure. Empirical evidence has shown that newly-founded banks are more likely to fail than older banks (Bickerdyke et al., 2000; Thornhill \& Amit, 2002). Given this background, we wanted to establish the relationship between bank age and failure probability in a Zimbabwean context given also that the banks which have failed so far were relatively new banks. A negative relationship is expected.

\subsubsection{Board Meetings Attendance}

According to the Central Bank`s Corporate Governance Guideline (CGG) 01/2004, every member of the board is expected to attend at least $75 \%$ of the board meetings of a banking institution to ensure that they discharge their duties and responsibilities effectively. Board meetings are also a statutory requirement as these are disclosed in the annual reports. A negative relationship between board attendance and bank failure is expected.

\subsubsection{Founder-Director Role}

Theory predicts that banks with large dominating shareholders - with easy control over management - tend to take more aggressive risks than manager-dominated banks with small disperse shareholdings, as diversified owners have stronger incentives to take aggressive risks than non-shareholding managers with bank-specific human capital and private control benefits (Jensen and Meckling, 1976; Galai and Masulis, 1976).

It was important to include this variable in the model in order to determine the exact relationship between bank failure and conflict of interest. A negative relationship is expected.

\subsubsection{Cost of Funds}

Higher deposit rates may act as an early warning signal of bank failure, a feature that has already been noticed in the empirical finance literature (e.g. Ellis and Flannery, 1992; Wheelock and Wilson, 1995). Moral hazard on bank owners can be exacerbated by a number of factors. First, an increase in the interest rate may lead borrowers to choose investments with higher returns when successful but with lower probabilities of success (Stiglitz and Weiss, 1981): hence, a rise in deposit rates could induce banks to adopt more risky investment strategies. A rise in bank lending rates can have similar incentive effects on the bank's borrowers. Thus, a positive relationship is expected between cost of funds and probability of failure.

\subsubsection{Error term}

The error term is important since it captures the influence of all independent or exogenous variables that are excluded from the model such as level of education of directors, number of board meetings and frequency, number of branches, etc. It also represents other factors that can influence the probability of default of a bank but not captured in the model. The error term is assumed to be normally distributed with a zero mean and constant variance (Gujarati, 2004).

\subsubsection{Constant}

According to Gujarati (2004), there is no real meaning derived from the constant but it is essential in the model because it shows autonomous default. This is something that is always there in the market even before the bank starts operating, there is failure risk.

\section{Diagnostic Tests}

A series of diagnostic tests were performed in order to test for econometrics a priori postulations, that is, to find whether the data collected and used abide to such requirements or not. 


\subsection{Multicollinearity}

Multicollinearity is the correlation between explanatory variables used in a regression model (Maddala, 2010). According to Gujarati (2004), any explanatory variables used for regression purpose must not be highly collinearly related, that is, their collinearity must not exceed $80 \%$. A correlation matrix of explanatory variables was used to test whether multicollinearity was present or not. The null hypothesis tested was that the model suffered from multicollinearity against the alterative that is, the model was free from multicollinearity.

\subsection{Variable Significance \& Worthiness Tests}

Significance tests were used to determine whether a particular variable was making a useful contribution to the model. We employed the one tailed $t$-test at $95 \%$ confidence interval using 24 degrees of freedom to ascertain the usefulness of the twelve variables to the overall model and $10 \%$ probability for the worthiness tests. The decision rules of accepting the significance of a variable are where $t$-stat $>t$-calc for variable significance tests and $t$-calc $>t$-stat for worthiness tests.

\subsubsection{Robustness Checks}

We ran robustness checks by comparing predictive power of the model against a classical Altman Z Score Model which has a prediction accuracy rate of $95 \%$. This was to ensure results were consistent with classical models and variances were investigated and explained.

\subsubsection{Goodness of Fit Measure}

Goodness of fit measure is the Pseudo $\mathrm{R}^{2}$ as proposed by McFadden in 1974.The goodness of fit would be close to 0 if the regression has no explanatory power, and if very good, would be close to 1 . Otherwise, $R^{2}$ of $0.2-0.4$ is for a good model, according to McFadden.

\subsubsection{Accuracy Rate}

A classification matrix which is a matrix containing numbers that reveal the predictive ability of the model was used. The overall accuracy rate is the percentage of correct classification to total classifications. This overall accuracy rate can be separated into the accuracy rate of good predicted bankrupt firms and good predicted non-bankrupt firms.

\section{Data Analysis and Presentation}

\subsection{Multicollinearity Test}

The hypothesis was stated as follows:

$\mathrm{H}_{0:}$ model suffers from multicollinearity.

$\mathrm{H}_{1:}$ model is free from multicollinearity.

Table 2.1 Multicollinearity Test Results

\begin{tabular}{|c|c|c|c|c|c|c|c|c|c|c|c|c|}
\hline & LN_Afr & $\begin{array}{l}\text { Non_Perf } \\
\text { _Loans }\end{array}$ & $\begin{array}{c}\text { Insider_ } \\
\text { Loans }\end{array}$ & $\begin{array}{c}\text { Mgt_Av } \\
\text { _ Exp }\end{array}$ & ROE & WACOF & $\begin{array}{l}\text { Prud_Li } \\
\text { q_Ratio }\end{array}$ & $\begin{array}{c}\text { Dep_ } \\
\text { Size }\end{array}$ & $\begin{array}{c}\text { Larg_ } \\
\text { Shareho } \\
\text { lder }\end{array}$ & $\begin{array}{c}\text { Bank_ } \\
\text { Age }\end{array}$ & $\begin{array}{l}\text { Board } \\
\text { Att }\end{array}$ & $\begin{array}{l}\text { Active_ } \\
\text { Founder }\end{array}$ \\
\hline LN_Afr & 1.000 & & & & & & & & & & & \\
\hline Non_Perf_Loans & -0.413 & 1.000 & & & & & & & & & & \\
\hline Insider_Loans & -0.614 & 0.253 & 1.000 & & & & & & & & & \\
\hline Mgt_Av_Exp & 0.435 & -0.322 & -0.349 & 1.000 & & & & & & & & \\
\hline ROE & 0.493 & -0.491 & -0.042 & 0.304 & 1.000 & & & & & & & \\
\hline WACOF & -0.288 & 0.183 & 0.326 & -0.023 & -0.251 & 1.000 & & & & & & \\
\hline Prud_Liq_Ratio & 0.529 & -0.526 & -0.563 & 0.230 & 0.258 & -0.464 & 1.000 & & & & & \\
\hline Bank_Size & 0.656 & -0.367 & -0.286 & 0.341 & 0.449 & -0.032 & 0.164 & 1.000 & & & & \\
\hline Larg_Shareholder & -0.399 & -0.041 & 0.286 & -0.229 & -0.178 & -0.024 & 0.233 & -0.452 & 1.000 & & & \\
\hline Bank_Age & 0.282 & -0.223 & -0.564 & 0.150 & 0.081 & -0.402 & 0.383 & 0.150 & -0.060 & 1.000 & & \\
\hline Board_Att & 0.240 & 0.034 & -0.094 & 0.172 & -0.045 & 0.165 & 0.347 & -0.046 & 0.180 & 0.076 & 1.000 & \\
\hline Active_Founder & -0.601 & -0.031 & 0.569 & -0.290 & -0.366 & 0.498 & -0.488 & -0.268 & 0.238 & -0.340 & -0.131 & 1.000 \\
\hline
\end{tabular}

The results from Table 2.1 above show that there is no collinearity among the variables as correlations ranged between 0.023 and 0.656 . Therefore, it means that these explanatory variables are independent of one another, hence we reject the null hypothesis that the model suffers from multi-collinearity. After running the model at $95 \%$ confidence level, the below tabulated results were obtained. 
Table 2.2 Logit Regression Results

\begin{tabular}{ccccccc}
\hline & Coefficients & Standard Error & t Stat & P-value & Lower 95\% & Upper 95\% \\
\hline Intercept & 35.5268 & 52.0245 & 0.6829 & 0.5076 & -77.8248 & 148.8785 \\
LN_Afr & -2.0024 & 3.0791 & -0.6503 & 0.04277 & -8.7111 & 4.7063 \\
Non_Perf_Loans & 31.4907 & 25.5708 & 1.23151 & 0.0066 & -2.4351 & 65.4164 \\
Insider_Loans & 56.084 & 67.0956 & 0.8359 & 0.004196 & -90.1047 & 202.2727 \\
Mgt_Av_Exp & -0.1803 & 0.2609 & -0.691 & 0.065027 & -0.3881 & 0.7487 \\
ROE & -3.1101 & 9.3373 & -0.3331 & 0.07448 & -23.4542 & 17.2341 \\
WACOF & 42.4612 & 46.541 & 0.9123 & 0.003796 & -58.943 & 143.8653 \\
Prud_Liq_Ratio & -1.7506 & 13.8069 & -0.1268 & 0.009012 & -31.8331 & 28.332 \\
Bank_Size & -1.111 & 31.2353 & -0.0356 & 0.09722 & -69.167 & 66.9449 \\
Larg_Shareholder & 7.8708 & 5.7753 & 1.3629 & 0.0198 & -4.7124 & 20.4541 \\
Bank_Age & -0.0232 & 0.0419 & -0.5542 & 0.05896 & -0.1146 & 0.0681 \\
Board_Att & -23.0634 & 12.7152 & -1.8138 & 0.0948 & -50.7675 & 4.6407 \\
Active_Founder & 3.0229 & 5.6398 & 0.536 & 0.06018 & -9.2652 & 15.311 \\
\hline
\end{tabular}

Given the above results, the resultant multiple regression model was deduced to be:

$Z=35.5268-2.0024$ LN_Afr +31.4907 Non_Perf_Loans +56.0840 Insider Loans - 0.1803 Mgt_Av_Exp - 3.1101 ROE + 42.4612 WACOF - 1.7506 Prud_Liq_Ratio - 1.1110 Bank_Size + 7.8708 Larg_Shareholder - 0.0232 Bank_Age - 23.0634 Board_Att + 3.0229 Founder_Director

Table 2.3 Regression Results

\begin{tabular}{cc}
\hline Regression Statistics & \\
\hline Multiple R & 0.920396 \\
R Square & 0.847129 \\
Adjusted R Square & 0.694258 \\
Standard Error & 5.638902 \\
Observations & 25 \\
\hline
\end{tabular}

The model shows that insider loans, non perfoming loans and funding costs are the major drivers of bank Probability of Failure (PF) in Zimbabwe as shown by the high coefficients of 56.08, 31.49 and 42.46, respectively. Further, the results indicate that, in line with economic theory, the PF is negatively correlated to regulatory capital level, average management experience, earnings, liquidity ratio, bank size, main board meetings attendance and bank age. Thus, empirical evidence suggests these factors reduce bank failure probability. Banks that are well capitalized in terms of regulatory capital and have good earning profiles are less likely to experience distress in the next twelve months.

Similarly, the PF is positively related to non performing loans ratio, insider loans, weighted average cost of funds, stock held by the largest shareholder and involvement of the founder in the management of the bank, thus these increase the probability of failure of a bank.

There is also significant evidence in favor of the market discipline hypothesis. The model shows that depositor discipline has an important signaling effect: when a bank pays more on deposits than its competitors, it has a significant impact on probability of distress. Those banks that "bargain for resurrection" in difficult times by increasing their deposit rates are more likely to experience financial distress in the next year. This finding is in line with some of the research on other countries, for example the results of Kraft and Galac (2007). Liquidity does not come out significant in the baseline estimation and this could be a result of the model trying to identify distress over a one-year window. When a bank's problems turn into a liquidity problem, it is often only very shortly (i.e. days) before intervention. Bank liquidity varies substantially over time, while the indicator accounts only for the amount of liquid assets banks hold in their portfolio as at the last day of financial reporting. Unfortunately, bank balance sheets do not show average liquidity over a certain reporting period to assess the average liquidity risk.

\subsection{Variable Significance \& Worthiness Tests Results}

We used one tailed $t$-test at 95\% confidence level and 24 degrees of freedom (TINV 95\%, $24 d f)$ to determine the significance of each variable and obtained the following results:

Hypothesis 
$\mathrm{H}_{0}$ : $\mathrm{B} 1=1$ Reject the hypothesis that the variable is not a significant factor in determining probability of bank failure.

$\mathrm{H}_{1}$ : B1>1 Accept the hypothesis that the variable is a significant factor in determining probability of bank failure.

Table 2.4 Variable Significance Test Results

\begin{tabular}{|c|c|c|c|c|}
\hline Variable & t calc & $\mathrm{t}$ stat & Decision Rule & Conclusion \\
\hline LN_Afr & -0.6503301 & 0.0633658 & $\begin{array}{l}\mathrm{t} \text { calc lies outside acceptable region, } \\
\text { reject } \mathrm{H}_{0}\end{array}$ & Variable is significant \\
\hline Non_Perf_Loans & 1.2315112 & 0.0633658 & $\mathrm{t}$ calc $>\mathrm{t}$ stat, reject $\mathrm{H}_{0}$ & Variable is significant \\
\hline Insider_Loans & 0.8358826 & 0.0633658 & $\mathrm{t}$ calc $>\mathrm{t}$ stat, reject $\mathrm{H}_{0}$ & Variable is significant \\
\hline Mgt_Av_Exp & 0.6909937 & 0.0633658 & $\begin{array}{l}\mathrm{t} \text { calc }>\mathrm{t} \text { stat, reject } \mathrm{H}_{0} \\
\mathrm{t} \text { calc lies outside acceptable region, }\end{array}$ & Variable is significant \\
\hline $\mathrm{ROE}$ & -0.3330813 & 0.0633658 & reject $\mathrm{H}_{0}$ & Variable is significant \\
\hline WACOF & 0.9123389 & 0.0633658 & $\begin{array}{l}\mathrm{t} \text { calc }>\mathrm{t} \text { stat, reject } \mathrm{H}_{0} \\
\mathrm{t} \text { calc lies outside acceptable region }\end{array}$ & Variable is significant \\
\hline Prud_Liq_Ratio & -0.1267903 & 0.0633658 & $\begin{array}{l}\text { reject } \mathrm{H}_{0} \\
\mathrm{t} \text { calc lies outside acceptable region, }\end{array}$ & Variable is significant \\
\hline $\begin{array}{l}\text { Bank_Size } \\
\text { Larg_- }\end{array}$ & -0.0355694 & 0.0633658 & reject $\mathrm{H}_{0}$ & Variable is significant \\
\hline Shareholder & 1.3628519 & 0.0633658 & $\begin{array}{l}\mathrm{t} \text { calc }>\mathrm{t} \text { stat, reject } \mathrm{H}_{0} \\
\mathrm{t} \text { calc lies outside acceptable region, }\end{array}$ & Variable is significant \\
\hline Bank_Age & -0.5541753 & 0.0633658 & $\begin{array}{l}\text { reject } \mathrm{H}_{0} \\
t \text { calc lies outside acceptable region, }\end{array}$ & Variable is significant \\
\hline Board_Att & -1.8138433 & 0.0633658 & reject $\mathrm{H}_{0}$ & Variable is significant \\
\hline Active_Founder & 0.5359928 & 0.0633658 & $\mathrm{t}$ calc $>\mathrm{t}$ stat, reject $\mathrm{H}_{0}$ & Variable is significant \\
\hline
\end{tabular}

From the results, it can be concluded that all the variables used in the model were significant determinants of probability of failure.

Table 2.5 Variable Worthiness Test Results

\begin{tabular}{lllll}
\hline Variable & $\mathrm{t}$ calc & $\mathrm{t}$ stat & Decision Rule & Conclusion \\
\hline LN_Afr & -0.6503301 & 1.710882 & $\mathrm{t}$ stat $>\mathrm{t}$ calc,reject $\mathrm{H}_{0}$ & Variable is Worth \\
Non_Perf_Loans & 1.2315112 & 1.710882 & $\mathrm{t}$ stat $>\mathrm{t}$ calc,reject $\mathrm{H}_{0}$ & Variable is Worth \\
Insider_Loans & 0.8358826 & 1.710882 & $\mathrm{t}$ stat $>\mathrm{t}$ calc,reject $\mathrm{H}_{0}$ & Variable is Worth \\
Mgt_Av_Exp & 0.6909937 & 1.710882 & $\mathrm{t}$ stat $>\mathrm{t}$ calc,reject $\mathrm{H}_{0}$ & Variable is Worth \\
ROE & -0.3330813 & 1.710882 & $\mathrm{t}$ stat $>\mathrm{t}$ calc,reject $\mathrm{H}_{0}$ & Variable is Worth \\
WACOF & 0.9123389 & 1.710882 & $\mathrm{t}$ stat $>\mathrm{t}$ calc,reject $\mathrm{H}_{0}$ & Variable is Worth \\
Prud_Liq_Ratio & -0.1267903 & 1.710882 & $\mathrm{t}$ stat $>\mathrm{t}$ calc,reject $\mathrm{H}_{0}$ & Variable is Worth \\
Bank_Size & -0.0355694 & 1.710882 & $\mathrm{t}$ stat $>\mathrm{t}$ calc,reject $\mathrm{H}_{0}$ & Variable is Worth \\
Larg_ & & & & \\
Shareholder & 1.3628519 & 1.710882 & $\mathrm{t}$ stat $>\mathrm{t}$ calc,reject $\mathrm{H}_{0}$ & Variable is Worth \\
Bank_Age & -0.5541753 & 1.710882 & $\mathrm{t}$ stat $>\mathrm{t}$ calc,reject $\mathrm{H}_{0}$ & Variable is Worth \\
Board_Att & -1.8138433 & 1.710882 & $\mathrm{t}$ stat $>\mathrm{t}$ calc,reject $\mathrm{H}_{0}$ & Variable is Worth \\
Active_Founder & 0.5359928 & 1.710882 & $\mathrm{t}$ stat $>\mathrm{t}$ calc,reject $\mathrm{H}_{0}$ & Variable is Worth
\end{tabular}

To test for worthiness, we used one tailed $t$-tests at $10 \%$ probability and 24 degrees of freedom (TINV 10\%,24 df) to determine the significance of each variable and obtained the under listed results.

Hypothesis

$\mathrm{H}_{0}$ : $\mathrm{B} 1=1$ Reject the hypothesis that the variable is not a worth factor in determining probability of bank failure.

$\mathrm{H}_{1}$ : B1>1 Do not reject the hypothesis that the variable is a worth factor in determining probability of bank failure.

Thus, all the variables were found to be worth in explaining probability of failure. 


\subsection{Validating The Logit Model To Bank Published Financials}

The model was simulated to the one-year-prior-to-failure for failed banks and 2013 financials for non-failed banks to ascertain its relevance and predictive strength.

The probability of failure $(\mathrm{PF})$ is then given by:

$$
P F(z)=\frac{1}{1+e^{-Z}}
$$

where $Z$ is given by:

$Z=35.5268-2.0024$ LN_Afr +31.4907 Non_Perf_Loans +56.0840 Insider Loans - 0.1803 Mgt_Av_Exp - 3.1101

ROE + 42.4612 WACOF - 1.7506 Prud_Liq_Ratio - 1.1110 Bank_Size + 7.8708 Larg_Shareholder - 0.0232 Bank_Age

- 23.0634 Board_Att +3.0229 Founder_Director

Table 2.6 Simulation Results

\begin{tabular}{|c|c|c|c|c|c|c|}
\hline Institution & Model Z Score & $\begin{array}{c}\text { Probability Of } \\
\text { Failure } \\
\end{array}$ & $\begin{array}{c}\text { RBZ Sub } \\
\text { Rating }\end{array}$ & Risk Level & S\& $P$ & Moody's \\
\hline Standard Chartered & -13.06835755 & $0.00 \%$ & 1 & Insignificant & AAA & Aaa \\
\hline Barclays & -11.19397931 & $0.00 \%$ & 2 & Insignificant & AAA & Aaa \\
\hline Stanbic & -9.8092114 & $0.01 \%$ & 3 & Insignificant & AAA & Aaa \\
\hline CABS & -9.46796495 & $0.01 \%$ & 4 & Insignificant & AAA & Aaa \\
\hline MBCA & -3.99900925 & $1.80 \%$ & 5 & Insignificant & AAA & Aaa \\
\hline CBZ Bank & -3.96551676 & $1.86 \%$ & 6 & Insignificant & AAA & Aaa \\
\hline BancABC & -2.69675312 & $6.32 \%$ & $2 \mathrm{a}$ & Modest & $\mathrm{AA}+$ & Aa1+ \\
\hline $\mathrm{ZB}$ & -1.98517106 & $12.08 \%$ & $2 b$ & Modest & AA & $\mathrm{Aa} 2$ \\
\hline FBC & -1.70366315 & $15.40 \%$ & $2 \mathrm{c}$ & Modest & AA- & $\mathrm{Aa} 3$ \\
\hline NMB & -1.50326743 & $18.19 \%$ & $3 a$ & Average & $A+$ & A1 \\
\hline Ecobank & -1.49701811 & $18.29 \%$ & $3 a$ & Average & $\mathrm{A}+$ & A1 \\
\hline POSB & -1.47769748 & $18.58 \%$ & $3 a$ & Average & $\mathrm{A}+$ & A1 \\
\hline Steward & -0.00000013 & $50.00 \%$ & $5 a$ & Acceptable With Care & $\mathrm{BB}+$ & Ba1 \\
\hline Agribank & 3.07403538 & $95.58 \%$ & 10 & Bankrupt & $\mathrm{D}$ & $\mathrm{D}$ \\
\hline Metbank & 3.66361129 & $97.50 \%$ & 10 & Bankrupt & $\mathrm{D}$ & $\mathrm{D}$ \\
\hline Tetrad & 3.72887673 & $97.65 \%$ & 10 & Bankrupt & $\mathrm{D}$ & $\mathrm{D}$ \\
\hline Capital & 4.02438918 & $98.24 \%$ & 10 & Bankrupt & $\mathrm{D}$ & $\mathrm{D}$ \\
\hline $\mathrm{TN} * * *$ & 5.92598672 & $99.73 \%$ & 10 & Bankrupt & $\mathrm{D}$ & $\mathrm{D}$ \\
\hline Kingdom** & 7.34756559 & $99.94 \%$ & 10 & Bankrupt & $\mathrm{D}$ & $\mathrm{D}$ \\
\hline Allied & 9.1750898 & $99.99 \%$ & 10 & Bankrupt & $\mathrm{D}$ & $\mathrm{D}$ \\
\hline Renaissance* & 11.24664618 & $100.00 \%$ & 10 & Bankrupt & $\mathrm{D}$ & $\mathrm{D}$ \\
\hline Trust & 12.10419652 & $100.00 \%$ & 10 & Bankrupt & $\mathrm{D}$ & $\mathrm{D}$ \\
\hline Interfin & 13.35505411 & $100.00 \%$ & 10 & Bankrupt & $\mathrm{D}$ & $\mathrm{D}$ \\
\hline Royal & 13.37560499 & $100.00 \%$ & 10 & Bankrupt & $\mathrm{D}$ & $\mathrm{D}$ \\
\hline AfrAsia & 13.90061474 & $100.00 \%$ & 10 & Bankrupt & $\mathrm{D}$ & $\mathrm{D}$ \\
\hline
\end{tabular}

The model was back-tested with the data set compiled from 1999 to 2012 and used to predict 2013 position. Based on one-year-prior-to-failure financials for failed institutions and 2012 financials for non-failed banks, the following results were obtained and ranked according to probability of failure and rating as per RBZ Sub-Rating as well as S\&P and Moody's Ratings.

The obtained results are in line with the actual obtaining situation in the financial sector in Zimbabwe at the present moment. Average PF for the banking sector was simulated to be $53.21 \%$ which is consistent with World Bank and IMF (2013) ratings of the banking sector which was rated "highly fragile". Based on publicly available information, international banks (Standard Chartered, Stanbic, Barclays, and MBCA) have remained stable given their credit risk averse strategies as shown by high liquidity ratios and relatively low loans to deposits ratios of $57 \%$ and $62 \%$ against $18 \%$ and 93\% ratios of local banks, respectively on average. This is consistent with the model results as foreign stable banks were rated "AAA" under the S\&P Rating, "Aaa" under the Moody"s and "1" under the RBZ Sub Rating with insignificant risk and a failure probability below $1.80 \%$ in the period $t+1$ year. The banks remained strong in 2013 and going into 2014 with most of them offering competition through finer lending rates of as low as $6 \%$ to blue chip and quality clients which other struggling local banks cannot match given the weighted average funding costs of as high as 
$15 \%$. Because of their stability, the foreign banks have managed to attract low cost deposits whilst limiting the relatively wholesale deposits. In addition, foreign banks have been offering competition by offering clients same day value for cross border payments because of the stable liquidity positions which local banks, grappling from the liquidity challenges, cannot match, thus increasing their vulnerability.

The model managed to predict the failure of all the collapsed banks with good precision. On the other hand, local banks continue to struggle as liquidity challenges engulf the economy with the relatively small and young banks collapsing. Amongst the stable local banks are the big banks, CBZ, FBC, CABS, ZB and BancABC whose average life span is more than 15 years and these were classified under low failure in the period $t+1$. Given the public information at hand, the model correctly predicted failure of the institutions rated "extreme" as per the study definition where failure referred to either collapse, take over due to challenges, surrendering an operating licence or surveillance by the regulator under the Troubled \& Insolvent Banks Policy.

\section{Prediction Results}

When testing the performance of a model designed to predict bankruptcy, it is particularly interesting to review its ability to identify bankrupt firms as misclassification may result in wrong decisions and incurring unnecessary costs e.g. missing a failing bank. This calls for the aspiration to find a model that performs well in identifying both bankrupt and non-bankrupt banks and hence fewer errors.

An important property of the logistic model is its precision in terms of minimizing Type I and Type II errors. A Type I error occurs when the model fails to identify the distressed bank and a Type II error occurs when a healthy bank is falsely identified as distressed. To attribute a particular bank into one of the two categories (distressed versus healthy), one needs to set up a cutoff point in terms of the bank PF. All banks above that cutoff point are blacklisted as weak banks while all banks below that point are classified as healthy. A higher cutoff point results in a lower number of banks on the blacklist of weak banks, which tends to increase the Type I errors. Setting a lower cutoff point can reduce the Type I errors but at the expense of generating more Type II errors. The optimal cutoff point depends on the relative weights that an analyst puts on Type I and Type II errors (Petersen, 2006). To address the trade-off between Type I and Type II errors, we illustrated the sensitivity of Type I and Type II errors with respect to the choice of the cutoff point of $50 \%$ where PF greater than this was considered failure and vice versa. The table below shows the prediction classification generated by the model showing Type I and II errors.

Table 2.7 Prediction Classification

\begin{tabular}{|c|c|c|c|c|}
\hline & \multicolumn{2}{|c|}{ Failed } & \multicolumn{2}{|c|}{ Non Failed } \\
\hline Predicted Failure & Correctly Predicted & $92.31 \%$ & Type II Error & $0.00 \%$ \\
\hline Predicted Non Failure & Type I Error & $7.69 \%$ & Correct Prediction & $100.00 \%$ \\
\hline
\end{tabular}

Source: Computed Data from Model Results

The model correctly predicted $92.31 \%$ of the failures and mis - classified one bank under non failure whilst in actual fact it is under stress, thus the Type II error of $7.69 \%$. It is important to note that there was no Type I error. A situation that will be costly to a regulator is missing a stressed bank.

\section{Robustness Comparison}

\subsection{Testing Altman's Z Score Model}

To get a better understanding of its robustness and effectiveness, we tested Altman's (1968) model with the current sample of the banks using 2012 financials. Keeping the same coefficients and replacing the market value of equity by the book value for one of the variables, z-scores were calculated for each bank. The cutoff $\mathrm{z}$-score was set to 0.5 , the point that best discriminates between the bankrupt and non-bankrupt groups and the results obtained are as set out in the table below.

Table 2.8 Altman's Z Score Prediction Classification

\begin{tabular}{llrlr}
\hline & \multicolumn{2}{c}{ Failed } & \multicolumn{2}{c}{ Non Failed } \\
\hline Predicted Failure & Correctly Predicted & $60.00 \%$ & Type II Error & $40.00 \%$ \\
Predicted Non Failure & Type I Error & $0.00 \%$ & Correct Prediction & $100.00 \%$ \\
\hline
\end{tabular}

Source: Computed Data from Model Results

This was done as a test of the applicability and predictive power of Altman's Z Score on Zimbabwean banks as well as checking and benchmarking the prediction powers of the developed model and the Altman's Z Score model. 
The results show that Altman model correctly predicted $60 \%$ of the failures compared to $92.31 \%$ prediction by the model under study which entails a higher Type 11 error rate of $40 \%$ and results in misallocation of resources in terms of bank supervision allocating time and resources on safe banks.

The table below shows the Altman`s Z Score prediction of the sample of the banks under study and their respective failure classification.

Table 2.9 Comparison of Model against Altman`s Z Score Model

\begin{tabular}{|c|c|c|c|}
\hline Institution & Probability Of Failure & Risk Level & Altman`s Z Score \\
\hline Standard Chartered & $0.00 \%$ & Insignificant & Safe Zone \\
\hline Barclays & $0.00 \%$ & Insignificant & Safe Zone \\
\hline Stanbic & $0.01 \%$ & Insignificant & Safe Zone \\
\hline CABS & $0.01 \%$ & Insignificant & Safe Zone \\
\hline MBCA & $1.80 \%$ & Insignificant & Safe Zone \\
\hline CBZ Bank & $1.86 \%$ & Insignificant & Grey Zone \\
\hline BancABC & $6.32 \%$ & Modest & Grey Zone \\
\hline $\mathrm{ZB}$ & $12.08 \%$ & Modest & Grey Zone \\
\hline FBC & $15.40 \%$ & Modest & Grey Zone \\
\hline NMB & $18.19 \%$ & Average & Grey Zone \\
\hline Ecobank & $18.29 \%$ & Average & Grey Zone \\
\hline POSB & $18.58 \%$ & Average & Distress \\
\hline Steward & $49.18 \%$ & Acceptable With Care & Distress \\
\hline Agribank & $95.58 \%$ & Bankrupt & Distress \\
\hline Metbank & $97.50 \%$ & Bankrupt & Distress \\
\hline Tetrad & $97.65 \%$ & Bankrupt & Grey Zone \\
\hline Capital & $98.24 \%$ & Bankrupt & Distress \\
\hline $\mathrm{TN} * * *$ & $99.73 \%$ & Bankrupt & Distress \\
\hline Kingdom** & $99.94 \%$ & Bankrupt & Distress \\
\hline Allied & $99.99 \%$ & Bankrupt & Distress \\
\hline Renaissance* & $100.00 \%$ & Bankrupt & Distress \\
\hline Trust & $100.00 \%$ & Bankrupt & Distress \\
\hline Interfin & $100.00 \%$ & Bankrupt & Distress \\
\hline Royal & $100.00 \%$ & Bankrupt & Distress \\
\hline AfrAsia & $100.00 \%$ & Bankrupt & Distress \\
\hline
\end{tabular}

The Altman`s Z Score Model showed that the international banks (Standard Chartered, Barclays, Stanbic, MBCA and CABS) were consistent with our Model as they were rated in the "Safe Zone". Altman's Z Score Model wrongly classified the stable banks (CBZ, BancABC, FBC, ZB, Ecobank and NMB) into the "Grey Zone. It also mis-classified POSB as a "Distressed" bank whilst Tetrad, a failed bank according to the study definition was classified under "Grey Zone" instead of "Distress". However, it correctly predicted 60\% of the failures but gave a relatively high Type II error of $40 \%$ implying the regulator could have spent resources and time focusing on non-stressed banks. The graph below compares robustness of the Altman`s Model against our model.

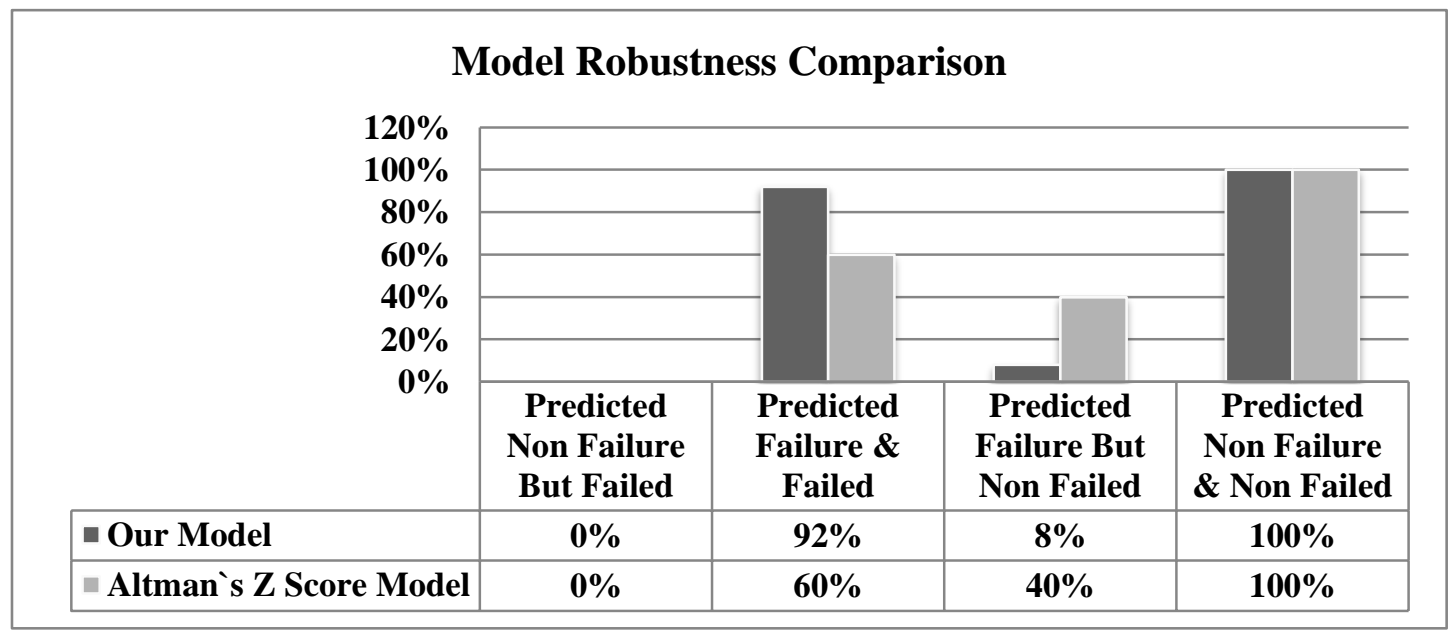

Figure 2.1 Robustness Comparison 
Possible Explanations for the Low Accuracy Rate of Altman's Z Score Model

The Altman's Z Score model may have produced a low accuracy rate due to different economic conditions between Zimbabwe and the USA where the model was developed as noted by Grice and Ingram (2001) who pointed out that researchers often mistakenly assumed that their models are stable across economic conditions that change over time, such as inflation, interest rates, and credit availability. The business environment of the mid-1900s, from which Altman's model was estimated, is drastically different from today's environment, thus the model is outdated and would not be accurate in current time. Altman's sample consisted of only manufacturing firms and as highlighted by Platt and Platt (1991), a model developed using firms from one set of industries may not be highly accurate in predicting bankruptcy for firms in other industries.

The other discrepancy could have emanated from differences in reporting requirements which could have since changed materially (Grice and Ingram, 2001) over time.

\subsection{Our Model Against RBZ Offsite CAMELS Ratings}

The researchers obtained offsite CAMELS Ratings done by the Regulator for the period one year to the reporting dates to assess the conditions of the banks based on the ratings. Ratings above "4" indicated stress and were used as a cutoff of high probability of failure and otherwise for ratings below " 4 ".

Table 2.10 CAMELS Ratings 2009 - 2013

\begin{tabular}{|c|c|c|c|c|c|}
\hline & Dec-09 & Dec-10 & Dec-11 & Dec-12 & Dec-13 \\
\hline Agribank & 3 & 4 & 3 & 4 & 4 \\
\hline BancABC & 2 & 1 & 3 & 3 & 3 \\
\hline Barclays & 1 & 2 & 2 & 3 & 2 \\
\hline CBZ & 2 & 2 & 3 & 2 & 2 \\
\hline FBC & 2 & 2 & 2 & $\begin{array}{c}2 \\
\text { Under }\end{array}$ & 2 \\
\hline Interfin & 3 & 3 & 4 & Curatorship & \\
\hline Kingdom & 2 & 3 & 3 & Taken Over & \\
\hline MBCA & 3 & 2 & 2 & 2 & 2 \\
\hline Metbank & 2 & 2 & 2 & 2 & 4 \\
\hline NMB & 3 & 2 & 2 & 2 & 3 \\
\hline Royal & & & 4 & 4 & Closed \\
\hline Stanbic & 2 & 1 & 1 & 1 & 1 \\
\hline Steward & & & & & 4 \\
\hline StanChart & 2 & 1 & 2 & 2 & 2 \\
\hline TN Bank & 3 & 3 & 3 & 3 & Taken Over \\
\hline Trust & & & 4 & 4 & Closed \\
\hline ZABG & 4 & 5 & 5 & 5 & 5 \\
\hline ZB Bank & 3 & 2 & 2 & 2 & 2 \\
\hline Genesis & 4 & 5 & 5 & Closed & \\
\hline Ecobank & 3 & 3 & 4 & 3 & 3 \\
\hline Renaissance & 4 & 4 & & Taken Over & \\
\hline Tetrad & 3 & 3 & 3 & 3 & 4 \\
\hline CABS & 2 & 2 & 2 & 2 & 2 \\
\hline POSB & 4 & 2 & 2 & 2 & 2 \\
\hline Capital & & & 3 & 4 & 4 \\
\hline AfrAsia & & & & 3 & 4 \\
\hline
\end{tabular}

The ratings confirm the 12 months in advance predictions done by the developed logit model as all banks that were rated above " 4 " were correctly predicted by the model well in advance. The CAMELS model thus gives a rating ex ante which makes it difficult for regulators to effectively and efficiently supervise banks. The main disadvantage then becomes an issue of realizing the poor rating of the bank historically resulting in late prescription of remedial actions like in the case of Interfin which technically failed under the regulator's nose.

\section{Conclusion}

The constructed model can be used as an analytical early warning decision support tool in both on-site and off-site bank monitoring system to detect banks that may be experiencing challenges. The ability to detect any problem in bank condition from publicly available data will also reduce the cost of monitoring banks by lessening the need for on-site examinations, and equally provide very valuable information to the decision makers as well as to other interested parties. The early warning signal could also be a veritable decision support tool for individual banks, the results of which will provide the basis for proactive measures that can forestall any emerging distress conditions. The model could be used as an alternative or supplementary decision support tool to the CAMELS rating system commonly employed by the RBZ 
in bank examination process.

\section{References}

Altman, E. (1968). Financial Ratios, Discriminant Analysis and The Prediction of Corporate Bankruptcy. The Journal of Finance, XXIII(4). http://dx.doi.org/10.2307/2978933

An Evaluation of the Factors Contributing to the Failure of National Banks in US (2011). Comptroller's Handbook "Community Bank Supervision" EP-CBS

Barr, R., \& Siems, T. (1994). Predicting Bank Failure Using DEA to Quantify Management Quality. Federal Reserve Bank of Dallas, Financial Industry Studies Working Paper, 1-94. http://dx.doi.org/10.1007/978-1-4615-4102-8_15

Beck, T., Demiguc-Kunt, A., \& Levine, R. (2006). Bank concentration, competition and crises: First results. Journal of Money, Credit and Banking, 1581-1603. http://dx.doi.org/10.1016/j.jbankfin.2005.05.010

Bickerdyke, I. (2000). Business Failure and Change: An Australian Perspective, Staff Research Paper, Productivity Commission AusInfo and Canberra. http://dx.doi.org/10.2139/ssrn.270772

Boyd, John H., \& David Runkle, 1993, Size and Performance of Banking Firms, Journal of Monetary Economics 31, 47-67. http://dx.doi.org/10.1016/0304-3932(93)90016-9

Brownbridge, M. (1998). The Causes of Financial Distress in Local Banks in Africa and Implications for Prudential Policy. UNCTAD Discussion Paper No. 1132. UNCTAD.

Calomiris, Charles W., \& Mason, Joseph R. Contagion and Bank Failures During the Great Depression: The June 1932 Chicago Banking Panic. American Economic Review, 87(5), 863-83. http://dx.doi.org/10.3386/w4934

Demirguc-Kunt, A. (1989). Banking Crises Around the World: Are There Any Common Threads?, Manuscript.

Demirguç-Kunt, A., \& Detragiache, E. (1998). Determinants of Banking Crisis: Evidence from Developed and Developing Countries, World Bank and IMF papers, E44 G21. http://dx.doi.org/10.5089/9781451947175.001

DeNicolò, G. (2000). Size, Charter Value and Risk in Banking: An International Perspective, International Finance Discussion Paper No. 689, Board of Governors of the Federal Reserve System. http://dx.doi.org/10.2139/ssrn.255465

Young. D. (1999). 'How Do Banks Make Money? The Fallacies of Fee Income, Federal Reserve Bank of Chicago Economic Perspectives, 28, 34-51.

Diamond, D. W., \& Philip, H. D. (1983). Bank Runs, Deposit Insurance, and Liquidity. Journal of Political Economy, 91(5), 401-19. http://dx.doi.org/10.1086/261155

Dziobek, C., \& Pazarbasioglu, C. (1997): Lessons From Systemic Bank Restructuring: A Survey of 24 Countries, IMF Working Paper 97/161. http://dx.doi.org/10.5089/9781451857788.001

Elegbe, A. (2013). Bank Failure and Economic Development in Nigeria: An Empirical Approach, British Journal of Economics, Finance and Management Sciences, 8(1).

Ellis, D. M., \& Flannery, M. J. (1992). "Does the Debt Market Assess Large Banks, Risk? : Time Series Evidence From Money Center CDs," Journal of Monetary Economics, Elsevier, 30(3), 481-502. http://dx.doi.org/10.1016/0304-3932(92)90008-p

Enoch, C., \& Green, J. (1997). Banking Soundness and Monetary Policy (Washington: International Monetary Fund).

Galai, D., \& Masulis, R. W. (1976). The Option Pricing Model and the Risk Factor of Stock. Journal of Financial Economics, 53-82. http://dx.doi.org/10.1016/0304-405x(76)90020-9

González-Hermosillo. (1996). Banking System Fragility: Likelihood versus Timing of Failure: An Application to the Mexican Financial Crisis. IMF Working Paper 142. Washington: International Monetary Fund (December). http://dx.doi.org/10.5089/9781451927535.001.

Goodhart, et al (1998). Financial Regulation Why, How, and Where now? Routledge, London.

Grice, J, S., \& Robert, W. I. (2001); Tests of the Generalizability of Altman's Bankruptcy Prediction Model. Journal of Business Research, 54(1), 53-61. http://dx.doi.org/10.1016/s0148-2963(00)00126-0

Gujarati, N. D. (2003). Basic Econometrics, Fourth Edition, McGraw-Hill, London

Hughes, J. P., \& Mester, L. J. (1998). Bank Capitalization and Cost: Evidence of Scale Economies in Risk Management and Signaling. Review of Economics and Statistics, 80, 314-325. http://dx.doi.org/10.1162/003465398557401

IMF Country Report No. 14/202, July 2014, http://www.imf.org 
IMF Country Report. (2003).

IMF Country Report. (2012).

Jensen, M. C., \& Meckling, W. H. (1976). Theory of the Firm: Managerial Behavior, Agency Costs and Ownership Structure. Journal of Financial Economics, 5, 305-360. http://dx.doi.org/10.1002/9780470752135.ch17

Kirkpatrick, G. (2009). The Corporate Governance Lessons from the Financial Crisis. Financial Market Trends. Paris, OECD Publication. http://dx.doi.org/10.2139/ssrn.2393978

Kraft, E., \& Tomislav, G. (2011). Substitution Between Domestic and Foreign Currency Loans in Croatia, CNB

Lanine, G., \& Vander, V. R. (2006). Microeconomic Determinants of Acquisitions of Eastern European Banks by Western European Banks, Working Papers of Faculty of Economics and Business Administration, Ghent University, Belgium 06/414, Ghent University, Faculty of Economics and Business Administration. http://dx.doi.org/10.1111/j.1468-0351.2007.00288.x

Maddala, G. S. (2010). Limited Dependent and Qualitative Variables in Econometrics, $3^{\text {rd }}$ edition. http://dx.doi.org/10.1017/ccol052124143x

Mamo, A. Q. (2011). Applicability of Altman (1968) Model in Predicting Financial Distress of Commercial Banks in Kenya. MBA Dissertation, School of Business University of Nairobi

Mishkin, F. S. (1999). Understanding Financial Crises: A Developing Country Perspective. Annual World Bank Conference on Development Economics, 29-62. http://dx.doi.org/10.3386/w5600

Ooghe H., \& Joos, P. (1995). Financial Distress Models in Belgium: The Results of A Decade of Empirical Research. International Journal of Accounting, 30, 245-274

Petersen, M. A. (2006). Estimating Standard Errors in Finance Panel Data Sets, Kellog Finance Department Working Paper, 329. http://dx.doi.org/10.3386/w11280

Platt, H. D., \& Platt, M. B. (1991); Development of A Class of Stable Predictive Variables: The Case of Bankruptcy Prediction. Journal of Business Finance and Accounting, 17(1), 31-51. http://dx.doi.org/10.1111/j.1468-5957.1990.tb00548.x

Reserve Bank of Zimbabwe Corporate Governance Guideline 01/2004

Reserve Bank of Zimbabwe. (2014) Monetary Policy Statement, http://www.rbz.co.zw, Lance Mambondiani, “Is RBZ Doing Enough?” The Newsday of 02 August 2012.

Reserve Bank of Zimbabwe. (2014) Monetary Policy Statement, http://www.rbz.co.zw

Reserve Bank of Zimbabwe. (2013). Monetary Policy Statement, http://www.rbz.co.zw

Shen Chung - Hue Meng Fen Hsieh. (2004). Prediction of Bank Failure Using Combined Micro and Macro Data, National Chengchi University

Stiglitz, J., \& Weiss, A. (1981). Credit Rationing in Markets with Imperfect Information, American Economic Review, 71(3), 84-96. http://dx.doi.org/10.2139/ssrn.1010965

Thornhill, S., \& Amit, R. (2002). Learning About Failure: Bankruptcy, Firm Age and The Resource Based View. Organization Science, 14(5), 497-509. http://dx.doi.org/10.1287/orsc.14.5.497.16761

Wheelock, D. C., \& Wilson, P. W. (2000): Why Do Banks Disappear? The Determinants of U.S. Bank Failures and Acquisitions. The Review of Economics and Statistics, 41,21-36. http://dx.doi.org/10.1162/003465300558560

World Bank. (2013). African Development Indicators. Retrieved Accessed, from http://data.worldbank.org/data-catalog/africa-development-indicators.

\section{$(\mathrm{cc}) \mathrm{BY}$}

This work is licensed under a Creative Commons Attribution 3.0 License. 